\title{
Franciszka Themerson and the Gaberbocchus Press: Bestlookers versus Bestsellers
}

If Franciszka and Stefan Themerson had stayed in Paris during World War Two, ${ }^{1}$ Gaberbocchus Press would never have existed. For its founders, its creation in 1948 had the therapeutic role of immersing them in the culture they had left behind on the continent. It allowed them to publish their own works and to introduce their favorite avant-garde authors to an English speaking audience.

While running the Press for thirty-one years, the Themersons drew from their deep knowledge of avant-garde art and literature acquired in their youth in native Poland, refined and deepened in Paris. Stefan, philosopher, writer, poet, filmmaker, and Franciszka, painter, draughtswoman, illustrator, cartoonist, and graphic designer, combined their energies and talents to create one of the most innovative and original publishing houses ever. The fact that they worked in different mediums didn't mean they differed in the way they perceived art and the world. Just the contrary. As unique as each of them was, they shared a very similar type of sensibility, imagination, humor and skepticism about Ultimate Truths. Such a cohesive system of values can clearly be sensed behind the creations of Gaberbocchus Press.

The marriage of the love for words with the passion for images produced results that would inspire generations of publishers to come. Joining elegance with the spirit of the avant-garde, being both readerand looker-friendly, Gaberbocchus Press remained ever astonishing in its artistic choices. Needless to say, it was never a financial success

${ }^{1}$ In 1938, the Themersons moved from Warsaw to Paris. Upon the outbreak of the war, they both volunteered for the Polish Army in France. In 1940, Franciszka arrived in London where she continued working as a cartographer for the Polish Government-inExile. Stefan's regiment disintegrated in 1940. Two years later he finally managed to join Franciszka in London. 
(which was not its goal), but the intellectual and artistic impact it had on writers, artists, readers, and publishers on both sides of the Ocean cannot be overestimated. Asked for a role model they had in mind, the most ambitious independent publishers would name Gaberbocchus. Today, after more than half a century, its publications still bring all sorts of pleasures: visual, intellectual, and tactile. The size of the books, so perfectly fitting into the readers hands, make modern albums and coffee table monsters seem even more arrogant.

The name of the press was a reference to Jabberwocky from Lewis Carroll's Through the Looking-Glass, which was Franciszka's (as well as many Surrealists') favorite reading. The Themersons adopted it in its Latin translation. After having met the White Queen and White King on the other side of the looking-glass, Alice finds a book written in an unintelligible language. She guesses that it has to be held up to a mirror and thus she reads a nonsense poem of seven strophes. In his copy of the book, Stefan marked the fourth strophe:

And, as in uffish thought he stood,

The Jabberwock, with eyes of flame,

Came whiffling through the tulgey wood,

And burbled as he came!

Gaberbocchus' logo, a winged dragon immersed in reading, playing with or presenting its pen/sword dripping with ink, is a symbol of the couple's philosophy.

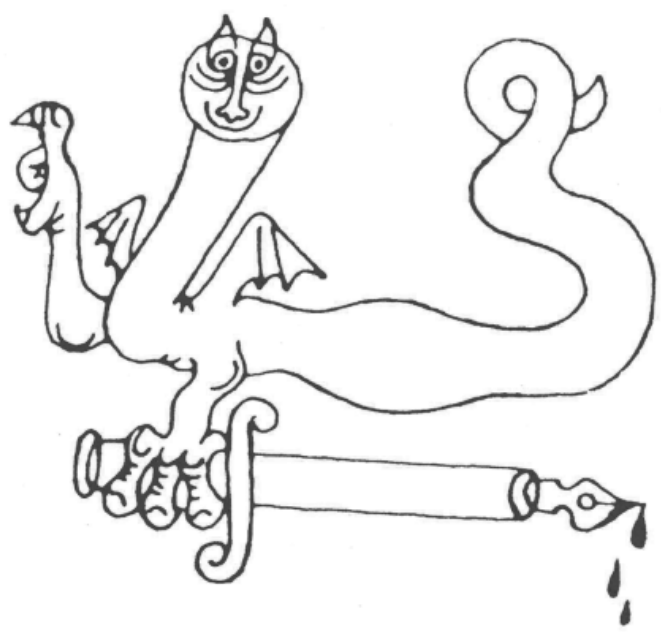

Figure 1. FranciszkaThemerson, Gaberbocchus logo, drawing, c. 1955 (from an archive of Marcin Giżycki) 
Like Alice in Wonderland, the Themersons believed that words were not enough: good books also need illustrations. ${ }^{2}$ Like Lewis Carroll, they excelled in playing with language and used nonsense and humor (often dark humor) to convey serious messages. This was the feature of English literature they valued the most. Gaberbocchus paid tribute to nonsense, Alfred Jarry's Pataphysics and Raymond Queneau's alternative vision of the world. It aimed at simultaneously seducing the intellect and the aesthetic sensibility of its readers. It enticed them with the appetite for both literary and visual adventure. It contradicted clichés, defied categories and classifications. It remained unique.

The Themersons published over 60 titles including the first English translations of such writers as Guillaume Apollinaire, Alfred Jarry, Raymond Queneau, Kurt Schwitters, Heinrich Heine, Raoul Haussmann, Anatol Stern, Bertrand Russell and George Buchanan. They planned, but did not manage to translate and publish Douanier Rousseau, Henri Michaud, Tristan Tzara, and many others. As impressive as this list is, it does not give an idea of how innovative were the typography and the design of the books published by Gaberbocchus. Together with their choice of authors, it was design and typography which became the trademark of their press.

Franciszka was the art director and illustrator for almost all Gaberbocchus publications. Together with Stefan, they worked in the same spirit of close collaboration as they did earlier while making their experimental and animated films (first in Warsaw before the war and then in London). Stefan contributed the unique elegance and intelligence of language, as well as typographical inventions. Franciszka added revolutionary ideas about the layout and the imaginative drawings filled with poetry and warm, albeit ironic, humor. These drawings not only illustrated the content, but often became the content accompanied by the text.

Their goal was to attain a perfect balance between content and form. Franciszka had gained experience illustrating children's books, first in Poland, then in France, and finally in England. Based on this experience and on her artistic sensibility she began the long term adventure during which she would fearlessly translate words into images and images into words.

As the art director of Gaberbocchus, she simultaneously used calligraphy, handwriting and the typewriter. The use of both typewriting

2 "[...] once or twice she had peeped into the book her sister was reading, but it had no pictures or conversations in it, 'and what is the use of a book', thought Alice, 'without pictures or conversations?"' (Carroll 1960: 25). 
and handwriting reflected her own artistic choice and was a continuation of experiments in the spirit of Dada conducted by artists from her and previous generations.

From the $1940^{\mathrm{s}}$ on, Franciszka Themerson's published drawings were less often illustrations and more and more interpretations, or visual commentaries accompanying the text. Their style ranged from narrative through sharp provocation to discreet satire. Stefan's typography and Franciszka's illustrations met in The Eagle $\mathcal{E}$ the Fox $\mathcal{E}$ the Fox $\mathcal{E}$ the Eagle by Aesop (published in 1949) where a unique effect was achieved thanks to symmetries and inversions of sense. Hand-printed on hand-made paper, it was designed as an object to be touched as well as looked at.

The Aesop book legitimized the originality of the newly founded house. The volumes that followed had one thing in common: they all derived form from content. That's why Gaberbocchus publications are so diversified. The book-as-object approach culminated in Stefan Themerson's Kurt Schwitters in England 1940-1948. Assembled from a variety of colored papers, this book-collage paid subtle tribute to Schwitters's art. It set a standard for imaginative book design that was unique at that time.

Asked about their press' main strengths and weaknesses, Stefan always gave the same answer: "refusal to conform". The "unclassifiability" of Gaberbocchus is its essential characteristic (Wadley 1996).

Most of the titles were first printed in one thousand copies plus a luxury edition of two hundred. The Themersons wanted their books to appeal to the readers' aesthetic sense, to convey to them the spirit of literature (which for each book meant a different thing). They claimed to be more interested in producing bestlookers than bestsellers (Wadley 1996).

This philosophy resulted in a unique and innovative integration of typography and image. Even though the technological means the Themersons had at their disposal were often limited (for example, they did only one color printing on basic paper), the typographic clarity always led to unpredictable solutions in which all page ingredients seemed inseparable. They treated book design as a visual metaphor, yet always respected the author and the reader. Clearly structured text combined with Franciszka's gestural drawings became the visual fingerprint of Gaberbocchus books.

Their collaboration expressed itself in a particularly eccentric way in Semantic Divertissements (1962, written 1949-1950), signed Themerson \& Themerson. 


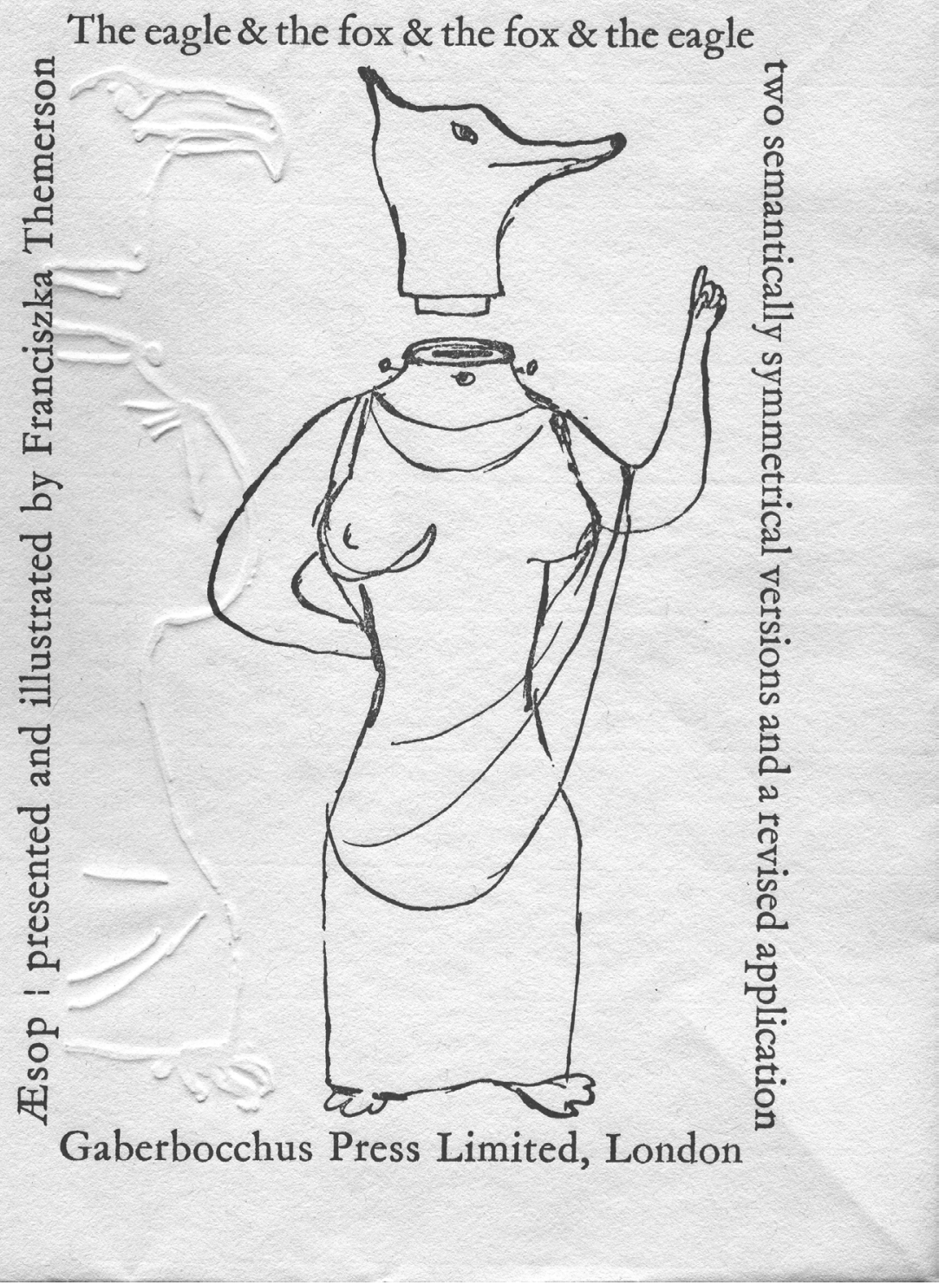

Figure 2. Franciszka \& Stefan Themerson, Aesop, The Eagle \& The Fox $\mathcal{E}$ The Fox $\mathcal{E}$ The Eagle, cover, 1949 


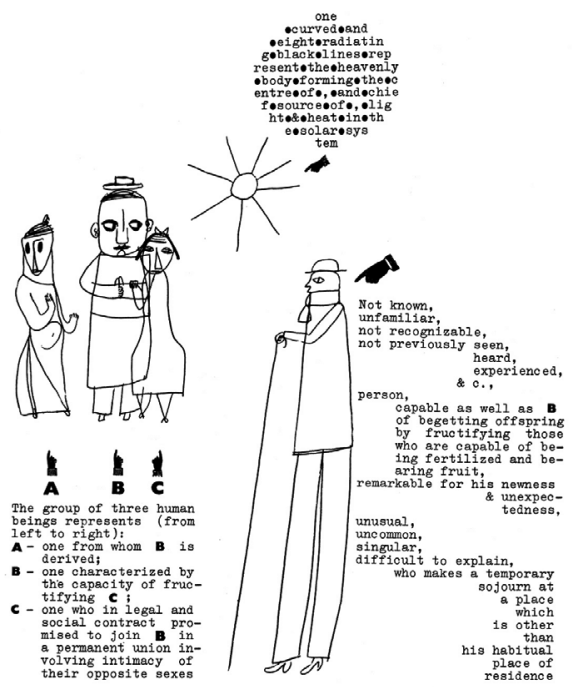

Figure 3. Franciszka \& Stefan Themerson, Semantic Divertissements, page 5, A Stranger, 1946 (published 1962)

Franciszka often, too often, destroyed her works, but she did keep a series of ball-point pen drawings made in the mid-1940. The poses and expressions of the characters in these drawings are eloquent yet difficult to interpret. Stefan accompanied them with the text which he typed and wrapped around the figures, thus making a sort of a painting. His interpretations of Franciszka's drawings bring to mind stiff and boring dictionary definitions. Stefan and Franciszka probably worked together to arrange the drawings in a sequence. The ambiguous naiveté of the characters found its echo in the text, creating a comical and disturbing effect. The simplicity of the lines refers to the transparency of the semantic language used in Stefan's text (and vice versa). Elaborate, diagrammatic drawings can be dissected and interpreted with the aid of philosophical, sometimes theological commentaries. The readers are faced with a tautological presentation that demonstrates the impossibility of translating between the visual and verbal languages. Coming from the Themersons, such a message reads as a provocation. 
Publishing Barbara's Wright's brilliant translation of the "untranslatable" masterpiece by Queneau, Exercises in style (which is an exploration into the possibilities of language and the functioning of its style), they proved that every book can be translated. Publishing dozens of books that interpret words with lines and lines with words, they showed that it is perfectly possible to translate from visual to verbal and the other way around.

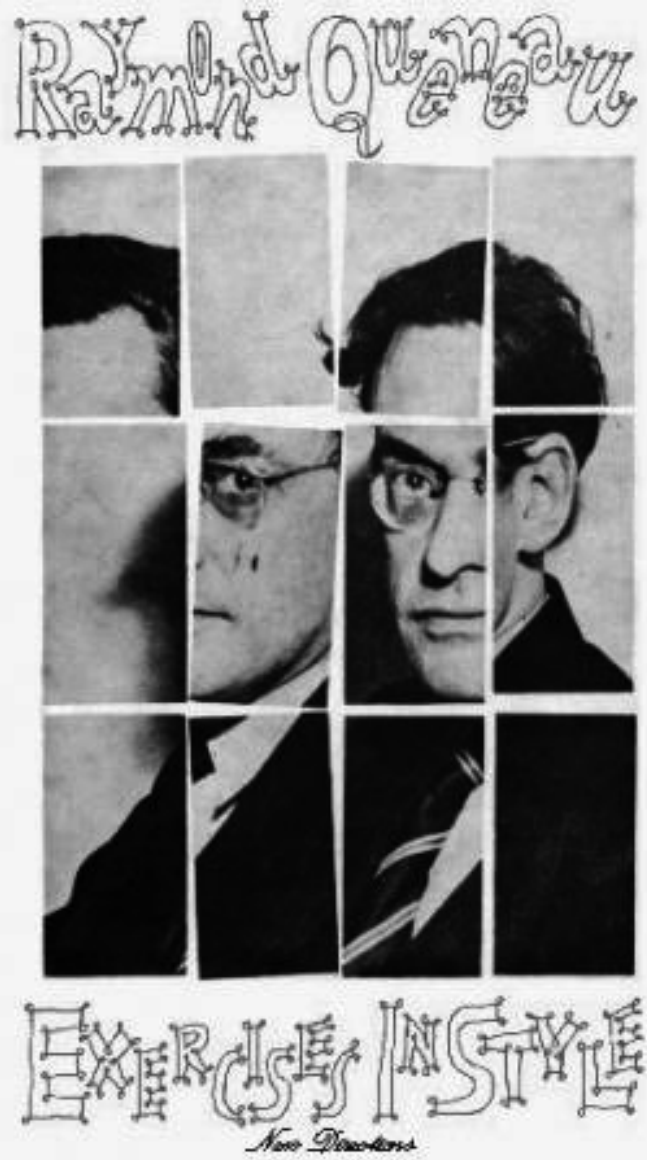

Figure 4. Stefan Themerson, Raymond Queneau, Exercises in Style, cover, 1958

Bertrand Russell's The Good Citizen's Alphabet (1953) played with the juxtaposition of typography and illustration through isolating word from image by large areas of white space. Thanks to this procedure the reader reacts to the text and the drawings separately. Franciszka's images do not illustrate the definitions by giving them a visual form. Rather, they create subtle contexts which, as Jan Kubasiewicz remarked in his essay 
on Gaberbocchus Press (Kubasiewicz 1993: 27), can result in a very clever and funny visual/verbal interpretation. The "trick" worked out perfectly. Russell claimed that Franciszka's illustrations "heightened all the points I most wanted to make" (Wadley 1991: 12; Wadley 1993: 61).

In 1951, Gaberbocchus Press published the first English translation of Alfred Jarry's Ubu Roi, the infamous play premiered in 1896, which shaped the imaginations of generations to come. It turned out to be the most widely acclaimed book of the Press. Franciszka had the idea to ask the translator, Barbara Wright, to write the text directly onto printing plates and then to add the layer of numerous drawings. The result was astonishing. The vibrating text entered into play with spontaneous images, the effect highlighted by the yellow paper on which the book was printed. Both the handwriting and the drawings seem liberated from the structure of the book as object. They wonderfully capture the savage nature of the narrative: the story of the terrifying anti-hero who watches the world from the perspective of his belly (gidouille). The revolutionary and capricious content of the play allowed an unpredictable visual form to emerge. The demand for it was such that the book was reprinted several times.

Franciszka also made masks for a reading at the Institute of Contemporary Arts in London (1952) and designed costumes and stage sets for a theatre production at Marionetteatern in Stockholm which has been touring since 1964. Her interest in Ubu, epitomizing the history of $20^{\text {th }}$ century wars and holocausts, culminated in the Ubu Comic Strip (created 1969-1970) (Themerson 2013). "She gives such authentic form to its hilarious futility that, by the end, Père Ubu appears as much a hapless victim of the world's madness as do those on whom he tramples", wrote Nick Wadley (1991: 15), the best commentator of Franciszka's oeuvre.

In her very personal book The Way It Walks (first published in 1954, then in 1988), she used quotes referring to the human condition written by such diverse authors as Herbert Read, Gaston Bachelard, Le Corbusier, Marcel Proust, Fenelon, Bertrand Russell, Winston S. Churchill, and others. With just a few lines, she gave them a subtle interpretation. The "wisdom-thoughts" often proved to be old clichés; "graphic elucidations" making their banality only more clear. Translating words into images helps to understand the former. The donkey on the front and back cover is unmistakably the artist's self-portrait.

The book's motto (Sir Walter A. Raleigh, Wishes of an Elderly Man, Wished at a Garden Party, June 1914) echoes Franciszka's subversive humor and her belief in the ridiculousness of human nature: 
I wish I loved the Human Race;

I wish I loved its silly face;

I wish I liked the way it walks;

I wish I liked the way it talks;

And when I'm introduced to one

I wish I thought What Jolly Fun!

(Themerson 1954)

Nick Wadley remembered, "Most often, her drawn images strike a profoundly pessimistic note. Looking through The Way It Walks, towards the end of her life, she commented to me that 'it hardly walks at all'" (Wadley 1991: 13).

Stefan Themerson used to say: "My bibliography is my biography; the rest is irrelevant". ${ }^{3}$ I am sure Franciszka wouldn't mind the credo: "My drawings, my paintings, and the books I designed are my biography. The rest is more than irrelevant".

\section{References}

Carroll, Lewis (1960). Alice's Adventures in Wonderland. New York: Bramhall House.

Kubasiewicz, Jan (1993). The Themersons and the Gaberbocchus Press - an Experiment in Publishing, 1948-1979. Eds. Jan Kubasiewicz and Monica Strauss. New York: MJS Books \& Graphics.

Themerson, Franciszka (1954). The Way It Walks. London: Gaberbocchus Press.

Themerson, Franciszka (1998-1999). Białe obrazy. Katalog wystawy. Galeria Kordegarda, Warszawa.

Themerson, Franciszka (2013). Ubu: według Ubu Roi Alfreda Jarry'ego. Łódź: Muzeum Sztuki.

Wadley, Nick (1991). "Lines from Life". In: The Drawings of Franciszka Themerson. Ed. Nick Wadley. Amsterdam: Gaberbocchus Press/Uitgeverij De Harmonie.

Wadley, Nick (1993). "The Two Ends of the Telescope". In: The Themersons and the Gaberbocchus Press - an Experiment in Publishing, 1948-1979. New York: MJS Books \& Graphics.

Wadley, Nick (1996). "Associés dans l'indépendence". In: Gaberbocchus Press: un éditeur non conformiste, Londres, 1948-1979. Cahiers d'une exposition, Paris: Bibliothèque nationale de France, 1996.

\footnotetext{
${ }^{3}$ As remembered by Jasia Reichardt and Nick Wadley.
} 